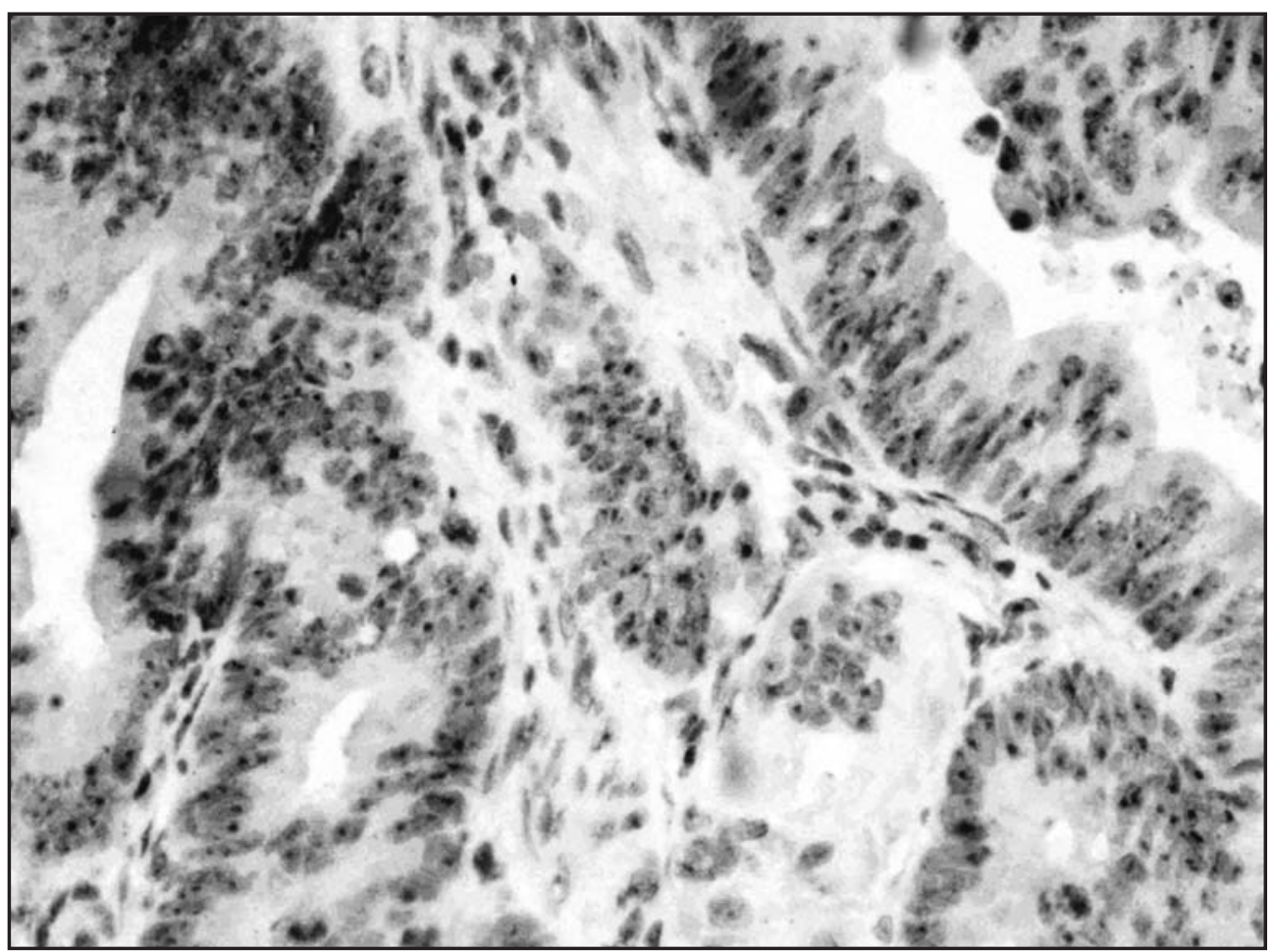

Fig. 3 Loss of expression of deleted in colorectal cancer protein in a moderately differentiated flat colorectal cancer x 200 (Pierderea expresiei DCC la un cancer colorectal cu diferențiere moderată, $\times 200$ )

\title{
Acknowledgements:
}

The authors thank Professor Ilan Hammel for his assistance.

\section{EXPRESIA PROTEINELOR ÎN DELETIIA GENEI CANCERULUI COLORECTAL ÎN ADENOCARCINOMUL COLORECTAL PLAT (SUPERFICIAL)}

Cuvinte cheie: cancerul colorectal plat, cromozom 18q, prognostic.

\section{Rezumat}

Obiectiv: Investigarea deleției cromozomiale în cancerul colorectal (DCC) folosind metode imunohistochimice, în carcinomul colorectal plat (CCRP) și evaluarea semnificației prognostice a acesteia în urmărirea pe termen lung.

Metode: Expresia DCC a fost identificată imunohistochimic în 15 probe tumorale incluse în parafină provenind de la pacienți cu CCRP. Urmărirea pacienților a fost de minim șapte ani.

Rezultate: Din cele 15 CCRP, opt au fost pozitive pentru DCC iar şapte au fost negative. Diametrul mediu al tumorilor cu expresie a DCC a fost $1,1 \pm 0,3 \mathrm{~cm}$, iar în cazurile negative 1,6 $6 \pm 0$ $(\mathrm{p}<0,05)$. Expresia DCC a fost observată în trei tumori bine diferențiate şi în cinci cu diferențiere 
moderată. Adâncimea medie a invaziei în cazurile pozitive a fost $5,0 \pm 2,3$ şi 2,6 $\pm 0,8$ cazurile negative $(\mathrm{p}<0,05)$. Invazia vasculară a fost identificată la o tumoră DCC negativă. Urmărirea cazurilor DCC pozitive a evidențiat supraviețuirea tuturor celor opt pacienți, fără semne de boală. La cazurile DCC negative, cinci $(71,4 \%)$ au supraviețuit fără a prezenta semne de boală, unul avea semne de invazie vasculară, iar un pacient cu recurență a decedat (28,6\%). Nu au fost diferențe semnificative între expresia DCC și vârstă, sex, localizarea tumorii, stadiul sau gradul de diferențiere tumorală.

Concluzii: Datele sugerează că pierderea expresiei DCC poate influența negativ prognosticul pacienților având carcinom colorectal. Expresia pozitivă a DCC în CCRP identifică pacienții cu prognostic mai bun.

\section{Introducere}

Carcinomul plat al colonului constă dintr-o leziune ușor elevată, aplatizată sau adâncită. Acest tip de leziune este mai frecventă în Japonia și rară în Europa și America de Nord [1]. Leziunile colorectale aplatizate sau adâncite sunt semnalate acum și la populația vestică. Potențialul malign, distribuția anatomică și alte atribute clinicopatologice nu au fost încă stabilite la acest grup populaţional [2].

Datorită lipsei datelor adecvate privitor la prevalența cancerului colorectal, caracteristicilor clinicopatologice și întârzierii validării noilor tehnologii colonoscopice la populațiile vestice, concepte care sunt deja bine stabilite în Japonia, nu s-a reușit un progres semnificativ în practica colonoscopică din Marea Britanie [3].

Deoarece CCRP a fost identificat ca un subtip de cancer mai agresiv, cu un potențial de invadare precoce în peretele colic, determinarea cu acuratețe a frecvenței lui poate avea implicații prognostice și terapeutice [4].

Progresia tumorală este un proces cu mai multe stadii, asociate $\mathrm{cu}$ alterări moleculare specifice. Acumularea graduală a acestor mutații multiple genetice este demonstrată de modificările celulare progresive.

Deleția genelor în cancerul colorectal poate fi un factor de predicție negativ pentru pacienții având carcinom colorectal. Deleția implică cromozomul 18q şi a fost identificată în carcinomul colonului [5]. Pierderea heterozigoticității cromozomului 18q şi/sau scăderea expresiei deleției a fost de asemenea observată în variate alte tipuri de cancere, incusiv gastrice, prostatice, endometriale, ovariene, esofagiene, de sân, testiculare, gliale, neuroblastoame şi afecțiuni maligne hematologice [6]. Pierderea alelei cromozomului $18 \mathrm{q} \mathrm{s}$-a dovedit a fi un factor predictiv negativ în cancerul de colon şi a fost asociată cu potențialul de metastazare [7].

Scopul acestui studiu a fost de a investiga expresia imunohistochimică a proteinelor DCC în CCRP şi semnificația ei prognostică.

\section{Materiale şi metode}

\section{Pacienți:}

Au fost colectate date de la cincisprezece cazuri consecutive de CCRP. Leziunile au fost depistate endoscopic, diagnosticate prin biopsie şi supuse rezecției chirurgicale. Criteriul de includere în studiu a fost urmărirea pe o perioadă de peste şapte ani. Tabelul I sumarizează datele clinice ale pacienților cu CCRP. Vârsta pacienților este între 55 şi 80 ani, cu o mediană 71,1 7 ,4, fiind nouă bărbați şi şase femei.

Din cele 15 cazuri, patru $(26,6 \%)$ au fost localizate la colonul drept (ascendent şi transvers) şi unsprezece $(73,3 \%)$ la colonul stâng (sigmoid şi rect).

După intervenția chirurgicală, toți pacienții au fost urmăriți anual prin colonoscopie şi evaluați pentru diseminarea sistemică a bolii, astfel încât a fost posibilă stabilirea duratei medii de supraviețuire fără diseminare. Niciunul din pacienți nu a primit tratament adjuvant. Urmărirea a fost între șapte și treisprezece ani. O pacientă care a prezentat o recurență a tumorii infiltrantă în ovar, la opt ani după prima intervenție, a decedat prin metastazarea bolii, alți trei pacienți au decedat în 2008 din alte cauze fără legătură cu malignitatea, iar unsprezece pacienți trăiesc și în prezent. 


\section{Piesele tumorale:}

Piesele rezecate au fost fixate cu formalină și înglobate în parafină. Toate lamele colorate cu hematoxilină-eozină ale fiecărui caz au fost evaluate de către doi anatomopatologi. Au fost înregistrate date patologice incluzând mărimea tumorilor, gradul histologic, statusul nodulilor limfatici regionali, prezența sau absența metastazelor la distanță, invazia angiolimfatică și perineurală, precum și stadiul patologic.

Profunzimea invaziei submucoase a cancerului a fost divizată în trei categorii conform Kudo S [8]: sm1 când tumora invadează treimea superioară a mucoasei, sm $2 \mathrm{cu}$ invazia treimei mijlocii și sm3 cu invazia limitei interne a muscularis propria. Stadializarea bolii a fost efectuată după sistemul TNM [9].

Imunohistochimie:

Pentru analiza imunohistochimică a fost ales un bloc de parafină care conținea tumora și mucoasa adiacentă, fiind efectuate secțiuni tisulare de patru microni, aplicate pe lamele acoperite cu polilisină, deparafinate și rehidratate. Antigenele au fost recuperate prin încălzirea secțiunilor tisulare la $90^{\circ}$ Celsius pentru 20 de minute într-un cuptor cu microunde, în soluție tampon 10nM de acid citric monofosfat ( $\mathrm{pH}$ 6,0). Marcarea imunohistochimică a fost efectuată utilizând anticorpi monoclonali de şoarece anti-DCC uman (clone G97-449, Pharmingen, San Diego, CA) la o diluție 1:40, peste noapte. A fost utilizat un spectru larg de anticorpi secundari (Histostain plus Bulk Kit $2^{\text {nd }}$ generation, Zymed Lab Inc. San Francisco, CA) conform instrucțiunilor producătorului. Lamele au fost colorate folosind colorația Mayer cu hematoxilină, rehidratate și apoi acoperite cu gelatină glicerol. Mucoasa normală a fost utilizată ca şi martor pozitiv, iar absența anticorpilor anti-DCC uman ca și martor negativ. Evaluarea expresiei proteinelor DCC a fost efectuată orb (față de datele clinice ale pacienților) de către doi anatomopatologi.

\section{Analiza statistică}

A fost utilizată analiza Student t-Test pentru prelucrarea datelor celor 15 cazuri, în vederea determinării existenței asocierii semnificative (i.e., $\mathrm{p}<0,05)$ între cele două grupuri [10].

Deși cei trei pacienți decedați anul trecut au avut ca și cauză a decesului alta decât neoplazia, nu au fost incluși în analiza statistică.

\section{Rezultate}

\section{Examinarea histopatologică}

Tabelul II cuprinde datele macroscopice şi microscopice ale celor 15 pacienți cu CCRP. Aspectul macroscopic al tumorii a fost aplatizat în zece cazuri și protruziv în cinci, conform clasificării japoneze [11]. Mărimea tumorilor a variat între 0,5 și $2,5 \mathrm{~cm}$, mediana $1,3 \pm 0,5$. Tumorile au fost încadrate ca și CCRP dacă invazia submucoasă a fost prezentă, dar cu o extensie minimă sau absentă în muscularis propria. Profunzimea invaziei submucoase a fost sm1 la nouă (60\%) pacienți, sm2 la doi (13,3\%) pacienți și sm3 la patru $(26,6 \%)$ pacienți. Invazia submucoasă a fost măsurată în milimetri, fiind între 2 și 9 mm, cu o mediană 3,9 $\pm 2,1$. Gradul tumoral a fost cu diferențiere bună în trei $(20 \%)$ cazuri și moderată în unsprezece $(80 \%)$ cazuri, nefiind evidențiat un grad scăzut de diferențiere. Invazia vasculară a fost prezentă la cazul $7 . \mathrm{Nu}$ a fost observată invazie perineurală. $\mathrm{Nu}$ au fost detectate metastaze în țesutul adipos peritumoral sau în nodulii limfatici, în niciunul din cazuri. La un caz au fost raportate metastaze la distanță, după recurența bolii. În toate cazurile diagnosticul inițial al stadiului a fost T1N0M0.

\section{Marcarea imunohistochimică}

Toate probele de mucoasă normală au fost puternic marcate pentru DCC. Marcarea a fost obținută în special în citoplasma celulelor care au furnizat un control pozitiv intern (Figura 1). Fibrele musculare ale mucoasei musculare au servit ca și control negativ. Din cincisprezece cazuri, marcarea a fost pozitivă la opt cazuri (Figura 2) şi negativă la şapte (Tabel III). DCC a fost pozitivă în şapte tumori în flancul drept şi în una în flancul stâng. Pierderea expresiei (Figura 3) a fost la trei tumori în flancul drept şi patru în flancul stâng. Diametrul mediu al tumorilor cu expresia DCC pozitivă a fost 


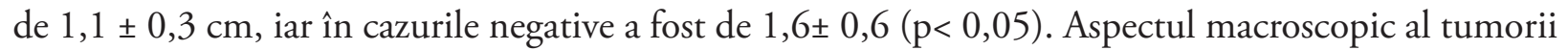
la cazurile DCC pozitive a fost aplatizat în patru situații şi protruziv în alte patru. La cazurile DCC negative doar unul a fost protruziv, iar restul aplatizate. Expresia DCC a fost observată la trei tumori bine diferențiate și la cinci moderat diferențiate. Absența expresiei DCC a fost observată la șapte cazuri cu tumori cu diferențiere moderată. Adâncimea medie a invaziei la cazurile pozitive a fost de $5,0 \pm 2,3$ şi de 2,6 $\pm 0,8$ la cazurile negative $(\mathrm{p}<0,05)$. Conform clasificării sm, şase cazuri pozitive au fost $s m 1$ şi două sm3. Din cazurile negative, trei au fost sm1, două sm2 şi două sm3. Invazia vasculară a fost observată la un caz DCC negativ. Urmărirea cazurilor DCC pozitive nu a evidențiat la niciunul din cei opt supraviețuitori semne de boală. Dintre cazurile DCC negative, cinci $(71,4 \%)$ trăiau, fără semne de boală, unul prezenta invazie vasculară, iar altul cu recurență a decedat $(28,6 \%) . \mathrm{Nu}$ au existat diferențe semnificative ale expresiei DCC privitor la vârstă, sex, localizarea tumprăă, stadiul, sau gradul de diferențiere.

\section{Discuții}

Studiul a investigat urmărirea pe termen lung a pacienților cu CCRP. Au fost observate diferențe semnificative statistic referitor la corelarea expresiei DCC cu diametrul macroscopic al tumorii. Profunzimea invaziei microscopice a avut de asemenea diferențe semnificative statistic între cazurile pozitive şi negative. Un rezultat important în ceea ce priveşte urmărirea pacienților este reprezentat de pierderea expresiei DCC la tumorile cu invazie vasculară, sau cu recurență. Aceste rezultate sunt în concordanță cu cele descrise în literatură şi anume că pierderea expresiei DCC este asociată cu un prognostic rezervat [12].

Majoritatea tumorilor DCC negative au fost tumori de aspect macroscopic aplatizat, iar tumorile pozitive au fost egal împărțite în aplatizate și protruzive. Toate tumorile DCC negative au avut un grad de diferențiere moderat, iar cazurile pozitive au avut o diferențiere parțial moderată și parțial bine diferențiate.

Într-un caz DCC negativ evoluția bolii a fost spre deces, prin diseminarea cancerului colorectal.

Gena DCC a fost propusă ca genă presupus supresoare, datele care susțin această propunere incluzând observații că o alelă DCC localizată pe cromozomul 18q, a suferit o deleție în peste $70 \%$ din cancerele colorectale și la un număr de alte tumori [5]. Cromozomul $18 \mathrm{q}$ a fost asociat cu un prognostic negativ la pacienții cu cancer colorectal fără metastaze în nodulii limfatici sau la distanță la momentul intervenției chirugicale (așa numitul stadiu II), precum și pentru pacienții cu metastaze la nivelul nodulilor limfatici și fără metastaze la distanță (stadiul III) $[13,14]$.

Mai multe studii $[15,16,17,18]$, au evaluat expresia DCC prin imunohistochimie, stabilind că aceasta este un factor de prognostic important în toate stadiile carcinomului colorectal.

Jessup și Loda [19] au analizat statusul actual al mai multor markeri moleculari, inclusiv DCC, concluzionând că evaluarea expresiei moleculelor în cancerul primar poate prezice răspunsul la terapie și evoluția bolii.

Leziunile aplatizate mici neoplazice cunosc o creștere a frecvenței la nivelul colonului [20]. Leziunile sunt considerate plate atunci când înălțimea lor nu depășește $50 \%$ din diametrul tumorii. Sunt carcinoame mici cu invazie submucoasă certă, denumite cancere plate sau superficiale. La momentul depistării lor, adenocarcinoamele superficiale pot să aibă o hiperplazie a țesutului lor adenomatos, ceea ce le poate face să semene cu carcinomul "de novo". Tumorile invazive tind să fie bine, sau moderat diferențiate [21]. Pacienții cu adenocarcinom colorectal stadiul I au tendința de a avea un prognostic bun, totuși fiind observate recurențe la unii pacianți [22]. 


\section{Concluzii}

Aceste rezultate sugerează că pierderea expresiei DCC poate influența prognosticul pacienților cu CCRP, iar expresia pozitivă a DCC identifică pacienții cu prognostic mai bun. După cunoștințele noastre, acesta este primul studi privind rolul DCC la pacienții cu CCRP.

Întrucât se cunosc puține despre mecanismele implicate în pierderea expresiei DCC în CCRP, sunt necesare cohorte mai mari de pacienți înainte de a putea trage concluzii definitive.

\section{Mulțumiri}

Autorii mulțumesc profesorului Ilan Hammel pentru ajutorul acordat.

\section{References (Referințe)}

1. Wada R, Matsukuma S, Abe H, Kuwabara N, Suda K, Arakawa A, Kitamura S. Histopathological studies of superficial-type early colorectal carcinoma. Cancer 1996;77:44-50.

2. Hurlstone DP, Cross SS, Adam I, Shorthouse AJ, Brown S, Sanders DS, Lobo AJ. A prospective clinicopathological and endoscopic evaluation of flat and depressed colorectal lesions in the United Kingdom. Am J Gastroenterol 2003;98:2543-2549.

3. Hurlstone DP, Brown S, Cross SS. The role of flat and depressed colorectal lesions in colorectal carcinogenesis: new insights from clinicopathological findings in high-magnification chromoscopic colonoscopy. Histopathology 2003;43:413-426.

4. Nasir A, Boulware D, Kaiser HE, Bodey B, Siegel S, Crawley S, Yeatman T, Marcet JE, Coppola D. Flat and polypoid adenocarcinomas of the colorectum: A comparative histomorphologic analysis of 47 cases. Hum Pathol 2004;35:604-611.

5. Fearon ER, Cho KR, Nigro JM, Kern SE, Simons JW, Ruppert JM, Hamilton SR, Preisinger AC, Thomas G, Kinzler KW, et al. Identification of a chromosome $18 \mathrm{q}$ gene that is altered in colorectal cancers. Science 1990;247:49-56.

6. Mehlen P, Fearon ER. Role of the dependence receptor DCC in colorectal cancer pathogenesis. J Clin Oncol. 2004;22:3420-3428.

7. Kato M, Ito Y, Kobayashi S, Isono K. Detection of DCC and Ki-ras gene alterations in colorectal carcinoma tissue as prognostic markers for liver metastatic recurrence. Cancer 1996;77:1729-1735.

8. Kudo S. Early Colorectal Cancer, Tokyo, Igaku-Shoin, 1996;88

9. Sobin LH, Wittekind Ch. TNM classification of malignant tumors, $5^{\text {th }}$ edition, Wiley-Liss, NY, 1997, pp 66-73.

10. Sokal RR, Rohlf FJ Biometry. Freeman, 1969, San Francisco.

11. Japanese Society for cancer of the colon and rectum: Japanese Classification of Colorectal Carcinoma, $1^{\text {st }}$ English Edition, Tokio, Kanehara, 1997;70.

12. Gal R, Sadikov E, Sulkes J, Klein B, Koren R. Deleted in colorectal cancer protein expression as a possible predictor of response to adjuvant chemotherapy in colorectal cancer patients. Dis Colon Rectum 2004; $47: 1216-1224$.

13. Jen J, Kim H, Piantadosi S, Liu ZF, Levitt RC, Sistonen P, Kinzler KW, Vogelstein B, Hamilton SR. Allelic loss of chromosome 18q and prognosis in colorectal cancer. N Engl J Med 1994;331:213-221.

14. Ogunbiyi OA, Goodfellow PJ, Herfarth K, Gagliardi G, Swanson PE, Birnbaum EH, Read TE, Fleshman JW, Kodner IJ, Moley JF. Confirmation that chromosome $18 q$ allelic loss in colon cancer is a prognostic indicator. J Clin Oncol 1998;16:427-433.

15. Shibata D, Reale MA, Lavin P, Silverman M, Fearon ER, Steele G Jr, Jessup JM, Loda M, Summerhayes IC. The DCC protein and prognosis in colorectal cancer. N Engl J Med 1996;335:1727-1732. 
16. Saito M, Yamaguchi A, Goi T, Tsuchiyama T, Nakagawara G, Urano T, Shiku H, Furukawa K. Expression of DCC protein in colorectal tumors and its relationship to tumor progression and metastasis. Oncology 1999;56:134-1341.

17. Reymond MA, Dworak O, Remke S, Hohenberger W, Kirchner T, Kockerling F. DCC protein as a predictor of distant metastases after curative surgery for rectal cancer. Dis Colon Rectum 1998;41:755-760

18. Schmitt CA, Thaler KR, Witting BM, Kaulen H, Buschenfelde KH, Dippold WG. Detection of the DCC gene product in normal and malignant colorectal tissues and its relation to codon 201 mutation. Brit J Cancer 1998;77: 588-594.

19. Jessup JM, Loda M. Prognostic markers in rectal carcinoma. Semin. Surg Oncol 1998;15:131-140.

20. Morita T, Tomita N, Ohue M, Sekimoto M, Yamamoto H, Ohnishi T, Tada M, Ikenaga M, Miyake Y, Sakita I, Tamaki Y, Matsuura N, Ito M, Monden M. Molecular analysis of diminutive, flat, depressed colorectal lesions: are they precursors of polypoid adenoma or early stage carcinoma? Gastrointest Endosc 2002;56:663-671.

21. Fenoglio-Preiser CM, Noffsinger, Stemmermann GN, Lantz PE, Listrom MB, Rilke FO. Gastrointestinal pathology: an atlas and text. Philadelphia, PA, Lippincott-Raven, 1999:981-982.

22. Di Gregorio C, Benatti P, Losi L, Roncucci L, Rossi G, Ponti G, Marino M, Pedroni M, Scarselli A, Roncari B, Ponz de Leon M. Int J Colorectal Dis 2005;20:147-154.

\section{Traducere (Translation): dr. Bumbuluț Călin}

